\title{
Isotopic variation of fishes in freshwater and estuarine zones of a large subtropical coastal lagoon
}

\author{
A.M. Garcia ${ }^{\mathrm{a}, *}$, D.J. Hoeinghaus ${ }^{\text {b,1 }}$, J.P. Vieira ${ }^{\mathrm{a}}$, K.O. Winemiller ${ }^{\mathrm{b}}$ \\ ${ }^{a}$ Departamento de Oceanografia, Laboratório de Ictiologia, Fundação Universidade Federal de Rio Grande, \\ CP 474, Rio Grande, RS, Brazil \\ ${ }^{\mathrm{b}}$ Section of Ecology and Evolutionary Biology, Department of Wildlife and Fisheries Sciences, Texas A\&M University, \\ College Station, TX 77843-2258, USA
}

Received 29 May 2006; accepted 2 February 2007

Available online 21 March 2007

\begin{abstract}
We used stable $\mathrm{C}$ and $\mathrm{N}$ isotope ratios of tissues from 29 fish species from a large subtropical lagoon in southern Brazil to examine spatial variability in isotopic composition and vertical trophic structure across freshwater and estuarine habitats. Nitrogen isotope ratios indicated a smooth gradation in trophic positions among species, with most fishes occupying the secondary and tertiary consumer level. Fish assemblages showed a significant shift in their carbon isotopic signatures between freshwater and estuarine sites. Depleted carbon signatures (from $-24.7 \%$ to $-17.8 \%$ ) were found in freshwater, whereas more enriched signatures (from $-19.1 \%$ to $-12.3 \%$ ) were obtained within the estuarine zone downstream. Based on our survey of the $\mathrm{C}_{3}$ and $\mathrm{C}_{4}$ plants and isotopic values for phytoplankton and benthic microalgae reported for ecosystems elsewhere, we hypothesized that the observed $\delta^{13} \mathrm{C}$ differences in the fish assemblage between freshwater and estuarine sites is due to a shift from assimilating organic matter ultimately derived from $\mathrm{C}_{3}$ freshwater marsh vegetation and phytoplankton at the freshwater site $\left(\delta^{13} \mathrm{C}\right.$ ranging from $-25 \%$ to $-19 \%$ ), to $\mathrm{C}_{4}$ salt-marsh (e.g. Spartina) and widgeon grass (Ruppia maritima), benthic microalgae and marine phytoplankton at the estuarine sites (from $-18 \%$ to $-12 \%$ ). Our results suggested that fish assemblages are generally supported by autochthonous primary production. Freshwater fishes that likely were displaced downstream into the estuary during periods of high freshwater discharge had depleted $\delta^{13} \mathrm{C}$ values that were characteristic of the upper lagoon. These results suggest that spatial foodweb subsidies can occur within the lagoon.
\end{abstract}

(C) 2007 Elsevier Ltd. All rights reserved.

Keywords: Brazil; estuary; freshwater discharge; food webs; Neotropical fishes

\section{Introduction}

Feeding relationships in nature involve numerous food chains meshed into complex food webs. In order to understand community structure and dynamics it is important to investigate direct and indirect effects of species interactions within food webs (Polis and Winemiller, 1996). The food-web approach has increased our knowledge of community dynamics via bottom-up and top-down regulation (Hairston et al.,

\footnotetext{
* Corresponding author.

E-mail address: amgarcia@mikrus.com.br (A.M. Garcia).

${ }^{1}$ Present address: Division of Biology, Kansas State University, Manhattan, KS 66502, USA.
}

1960) and the influence of keystone species (Paine, 1969). Food webs also provide a basis for interpreting or predicting impacts of exotic species on native biota (e.g. Zaret and Paine, 1973) or to evaluate global impact of unsustainable exploitation of renewable natural resources (e.g. Pauly et al., 1998).

Food-web analyses have been used to examine ecosystem structure and dynamics of estuaries throughout the world (Day et al., 1989). The principal primary production sources that sustain high secondary productivity in estuaries have been studied extensively and yet remain a major topic of debate (Litvin and Weinstein, 2003; Connolly et al., 2005). The role of organic detritus in linking estuarine primary producers to consumers is another topic of intense interest (Sobczak et al., 2005). 
The lack of direct grazing on marsh vegetation and abundance of dead plant material and other organic matter in sediments of estuaries has yielded the conclusion that detritus is the principal input at the base of estuarine food-webs (McLusky, 1989). Most detritus is digested by bacteria and other microorganisms (microbial loop), and many detritivorous metazoans depend on enzymes or biomass produced by microorganisms to derive nutrition from detritus (Nybakken and Bertness, 2005). Using traditional stomach contents analysis, it is difficult to determine the original sources of organic matter within aggregate pools of consumed detritus. In addition, it is almost impossible to estimate the nutritional value of organic detritus found within the digestive tract of a consumer (Jepsen and Winemiller, 2002).

Although limited in terms of taxonomic resolution, estimates of carbon sources sustaining consumers and vertical trophic structure based on stable isotope analysis (SIA) can overcome some of the methodological limitations associated with stomach content analysis (Peterson and Fry, 1987). SIA has been widely used to investigate flows of energy and materials through estuarine food webs (Peterson et al., 1985; Deegan and Garritt, 1997; Melville and Connolly, 2003; Doi et al., 2005). Overall, these studies revealed that the relative importance of primary production sources supporting estuarine consumers may depend on factors such as feeding mode, trophic position, habitat type and location within the estuary (Peterson et al., 1985; Peterson and Howarth, 1987; Deegan and Garritt, 1997).

Most estuarine food web investigations based on SIA have been conducted on temperate systems (e.g., Deegan and Garritt, 1997; Litvin and Weinstein, 2003) and on subtropical and tropical estuaries in Australia (e.g., Melville and Connolly, 2003; Cook et al., 2004), South Africa (e.g., Paterson and Whitfield, 1997), Japan and Southeast Asia (e.g. Kang et al., 2003; Doi et al., 2005). Despite the high biotic diversity and ecological importance of South American estuaries (Seeliger and Kjerfve, 2001) there are no published studies on estuarine food webs using SIA in this region. To our knowledge the only exception is the preliminary work of Abreu et al. (2006) that investigated eutrophication processes and basic trophic interactions in Patos Lagoon estuary.

We analyzed stable $\mathrm{C}$ and $\mathrm{N}$ isotope ratios to examine variability in isotopic composition and trophic positions of fishes between oligotrophic fresh waters and productive estuarine waters in a large subtropical lagoon in southern Brazil. We evaluated the hypothesis that consumers reflect assimilation of material from autochthonous primary producers. We analyze and discuss our findings in relation to species life cycles, available dietary information, and long-term studies of the fish assemblages conducted in this system over the past three decades.

\section{Material and methods}

\subsection{Study site}

Measuring 250 by $60 \mathrm{~km}$, Patos Lagoon $\left(32^{\circ} \mathrm{S} 49^{\circ} \mathrm{W}\right.$, South Brazil, Fig. 1) is one of the largest subtropical coastal lagoons in the world (Kjerfve, 1986). A single narrow entrance (0.5 to $3 \mathrm{~km}$ in width) in the south connects the lagoon with the South Atlantic Ocean. Estuarine-dependent and marine-vagrant fishes enter through this channel to use the estuary for protection and feeding opportunities (Chao et al., 1985). Physicochemical dynamics of Patos Lagoon estuary are determined by topographical and meteorological conditions, with the tidal range within the estuary limited to low diurnal amplitude (mean $=0.47 \mathrm{~m}$ ). The salinity regime in the estuary is a function of wind and regional precipitation (Castello, 1985).

The fish assemblage of Patos Lagoon is seasonally dynamic and receives species from both fresh and marine waters. The estuarine fish assemblage is composed of about 110 species, most of which are present in the estuary only for a portion of the year (Chao et al., 1985). Some fishes (e.g. Brazilian silverside, Atherinella brasiliensis) remain within the estuary throughout their lives, whereas many marine spawning fishes (e.g., mullets, Mugil platanus) use Patos Lagoon estuary as nursery grounds (Vieira and Castello, 1996). Patos Lagoon and the adjacent coastal area support one of the most important fisheries in the warm-temperate southwestern Atlantic (Haimovici et al., 1996).

The lagoon's drainage basin $\left(201,626 \mathrm{~km}^{2}\right)$ is one of the largest in Latin America (Seeliger and Kjerfve, 2001). Freshwater discharge varies seasonally, with high discharge in late winter and early spring followed by moderate discharge through summer and autumn. The mean annual discharge is ca. $2000 \mathrm{~m}^{3} \mathrm{~s}^{-1}$, although large year-to-year variation is observed (700 to $3000 \mathrm{~m}^{3} \mathrm{~s}^{-1}$ ) (Moller et al., 2001). During El Niño episodes, freshwater discharge can greatly reduce salinity for periods of up to six months. These periods of high freshwater flow greatly affect the fish assemblage in the estuarine reach (Garcia et al., 2004). Several freshwater fishes (e.g. freshwater catfish Parapimelodus nigribarbis, characid Astyanax eigenmanniorum, dog-tooth characid Oligosarcus jenynsii) spread throughout the estuary during this period. High freshwater outflow through the mouth impedes entry by juveniles of marine species that are otherwise common in the estuary (e.g., mullet Mugil platanus) and adults of marine vagrants (e.g., anchovy Anchoa marinii) normally present during summer months (Garcia et al., 2003a).

\subsection{Field collection and sample processing for isotopic analysis}

Primary producers and fishes were sampled at three locations within Patos Lagoon: in the upper freshwater portion of the lagoon (site A) and two sites (B and C) in the lower estuarine region (Fig. 1). Field surveys were conducted during a one-week period of November 2004 (late austral spring). Floating and emergent macrophytes were collected by hand, and fishes were collected using multiple gears (beach seines, cast nets and gillnets) to collect representative samples of the fish diversity at each site. At sites A and C, filter-feeding bivalves (freshwater golden mussel Limnoperna fortunei and the estuarine clam Erodona mactroides) were collected by hand for use as basal references in the calculation of trophic 

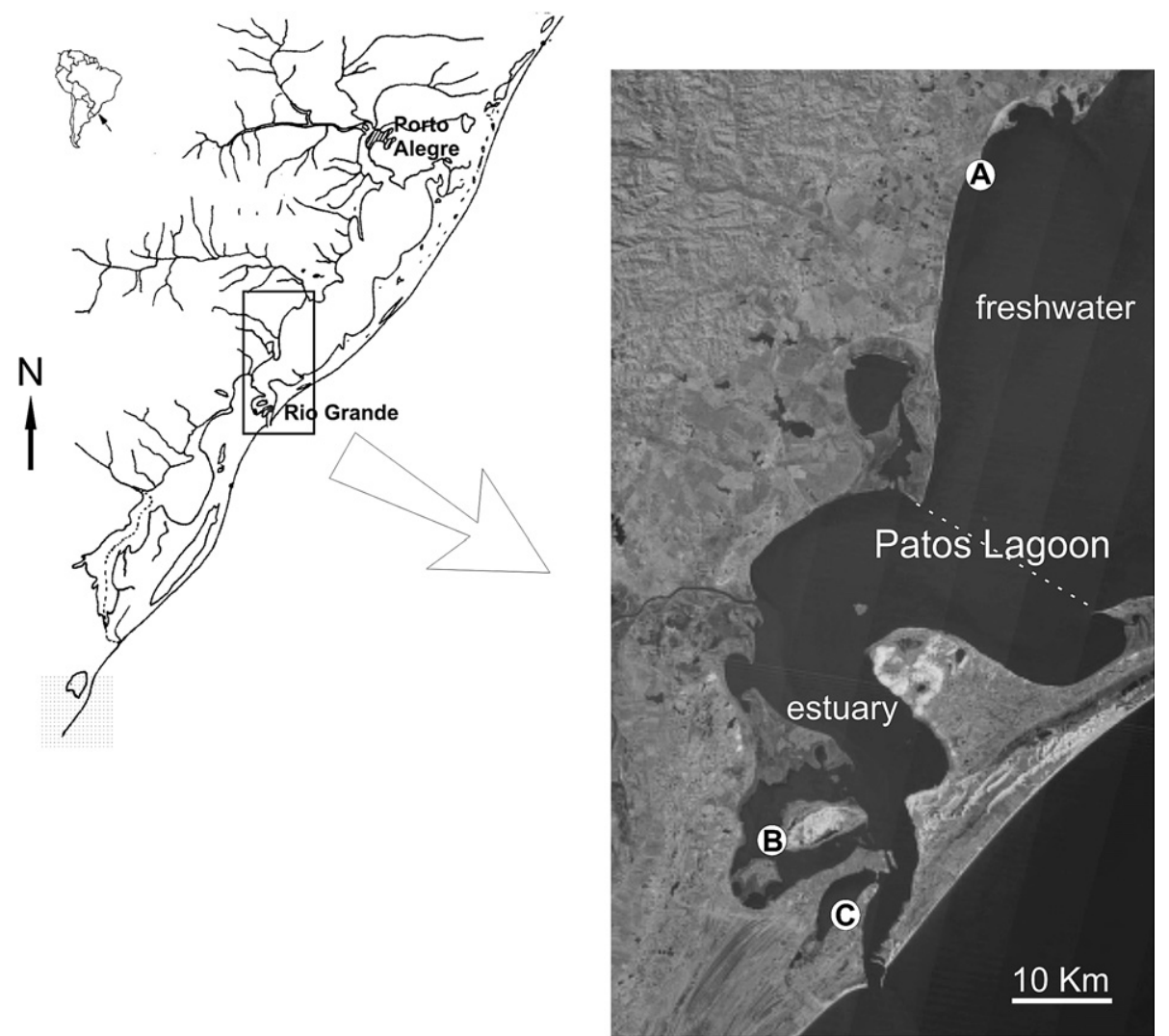

Fig. 1. Drainage basin of Patos-Mirim Lagoon complex $\left(32^{\circ} \mathrm{S} 49^{\circ} \mathrm{W}\right)$ in southern Brazil. Site A is located in the upper freshwater reaches of the lagoon, whereas sites $\mathrm{B}$ and $\mathrm{C}$ are located in the estuarine zone, near the connection of the lagoon with the sea. The dashed line represents the usual boundary between brackish and freshwater.

positions (see below). Because isotopic signatures of their shells reflect calcium carbonate assimilated from the environment, only muscle samples were used for SIA. Our isotopic data for plants at site $\mathrm{C}$ was complemented with information reported by Abreu et al. (2006).

All samples were placed on ice for transport to the laboratory where they were stored frozen. Samples for isotopic analysis consisted of several leaves for plant species, and approximately $5 \mathrm{~g}$ of dorsal muscle tissue from individual fish or, in the case of smallest size-classes $(<50 \mathrm{~mm}$ total length), a composite sample of individuals of approximately the same size was taken by combining pure muscle tissue from 5-15 individuals from the same site. For bivalves, the adductor was removed and processed for SIA in the same manner as fish samples. Thawed samples were carefully inspected to remove non-muscle matter (e.g. bone or scales in fish tissue), rinsed with distilled water, placed in sterile Petri dishes, and dried in an oven at $60^{\circ} \mathrm{C}$ to constant weight (minimum of $48 \mathrm{~h}$ ). Dried samples were ground to a fine powder with a mortar and pestle and stored in clean glass vials.

Sub-samples were weighed to $10^{-3} \mathrm{~g}$, pressed into UltraPure tin capsules (Costech, Valencia, CA), and sent to the Analytical Chemistry Laboratory, Institute of Ecology at the University of Georgia for determination of stable isotope ratios $\left({ }^{13} \mathrm{C} /{ }^{12} \mathrm{C}\right.$ and $\left.{ }^{15} \mathrm{~N} /{ }^{14} \mathrm{~N}\right)$. Results are reported as parts per thousand $(\%)$ differences from a corresponding standard: $\delta X=\left[\left(R_{\text {sample }} / R_{\text {standard }}\right)-1\right] \times 10^{3}$, where $R={ }^{15} \mathrm{~N} /{ }^{14} \mathrm{~N}$ or ${ }^{13} \mathrm{C} /{ }^{12} \mathrm{C}$. Standards were carbon in the PeeDee Belemnite and nitrogen in air. Standard deviations of $\delta^{13} \mathrm{C}$ and $\delta^{15} \mathrm{~N}$ replicate analyses were $0.14 \%$ and $0.13 \%$, respectively.

\subsection{Data analysis}

Scatter plots of $\delta^{15} \mathrm{~N}$ and $\delta^{13} \mathrm{C}$ values of fishes were used to evaluate patterns of isotopic variation across sampling stations. Sources of organic carbon assimilated by consumers are indicated by relative positions of taxa on the $x$-axis $\left(\delta^{13} \mathrm{C}\right.$ values), whereas trophic level is indicated by relative position on the $y$-axis $\left(\delta^{15} \mathrm{~N}\right)$ (Peterson and Fry, 1987). Analysis of variance (ANOVA) was used to compare $\delta^{13} \mathrm{C}$ and $\delta^{15} \mathrm{~N}$ of fish assemblages, and to compare isotopic variation within species among sites. When a significant main effect was observed, pairwise comparisons of site means were performed using Newman-Keuls post hoc procedure. For some analyses, fishes were pooled into four ecological categories identified by Garcia et al. (2003a): (1) estuarine residents, typically occurring and breeding within the estuary; (2) estuarine dependents, marine or freshwater spawning species found in large numbers within the estuary during certain periods of their life cycle; (3) marine vagrants, typically inhabiting marine habitats and rarely occurring within the estuary; and (4) freshwater vagrants, typically inhabiting freshwater habitats and rarely occurring within the estuary. 
Because heavier ${ }^{15} \mathrm{~N}$ accumulates in consumers as it moves up the food web, consumers tend to be $\delta^{15} \mathrm{~N}$ enriched by $2.5 \%$ to $3.5 \%$ relative to their food resources (Post, 2002; Vanderklift and Ponsard, 2003). Thus, $\delta^{15} \mathrm{~N}$ signatures of consumers relative to those of a base-line value can be used to indicate the trophic position of consumers. Nitrogen isotopic distributions were used to estimate trophic positions of consumers following the equation: $\mathrm{TP}=\lambda+\left(\delta^{15} \mathrm{~N}_{\text {predator }}-\delta^{15} \mathrm{~N}_{\text {bivalve }}\right) / F$, where $\lambda$ is the trophic level of consumers estimating the base of the food web (in this case $\lambda=2$ because bivalves are primary consumers), $\delta^{15} \mathrm{~N}_{\text {predator }}$ is the nitrogen signature of the consumer being evaluated, and $F$ is the per-trophic-level fractionation of nitrogen [in this case 2.54, following the metaanalysis of Vanderklift and Ponsard (2003)]. Other studies (Minagawa and Wada, 1984; Vander Zanden and Rasmussen, 1996) have suggested a fractionation value of approximately 3.4 , therefore when comparing our results with studies utilizing higher enrichment values, the trophic position values presented here should be considered upper estimates. Trophic positions were calculated only for those sites (A and C) where filter-feeding bivalves were obtained to estimate the base of the food web.

\section{Results}

Macrophytes revealed an increasing trend from depleted to more enriched $\delta^{13} \mathrm{C}$ signatures from freshwater (site A) to the estuary (sites B and C) (Table 1). However, this trend was not statistically significant $(p>0.051)$ due to contrasting signatures between plants using the $\mathrm{C}_{3}$ and $\mathrm{C}_{4}$ photosynthetic pathways, which co-occurred only in the estuarine sites. In contrast, plants showed a tendency to have more enriched $\delta^{15} \mathrm{~N}$ signatures at freshwater than in the estuary, although among-species variation, particularly in site A, precluded statistical significance $(p>0.103)$ (Table 1$)$.

We caught a total of 158 fishes representing 29 species (Table 2). The freshwater site (A) had lower number of sampled individuals (45) but higher number of species (19) than estuarine sites B (47 ind., 11 spp.) and C (66 ind., 12 spp.) (Table 2). Most of the species collected from site A were freshwater taxa, especially from the family Characidae. However, some estuarine-dependent fishes (e.g. white sea catfish Netuma barba, whitemouth croaker Micropogonias furnieri, silverside Odonthestes argentinensis) and estuarine-resident fishes (e.g. Atlantic sabretooth anchovy Lycengraulis grossidens, River Plate sprat Platanichthys platana) were also captured in the freshwater site. In contrast, only three freshwater species were caught at the two estuarine sites: the characid Astyanax eigenmanniorum, the trahira Hoplias malabaricus, and the pearl cichlid Geophagus brasiliensis (Table 2, Fig. 2).

Fish assemblages showed overall differences in $\delta^{13} \mathrm{C}$ signatures between freshwater and estuarine sites, with depleted carbon signatures (from $-24.7 \%$ to $-17.8 \%$ ) in the freshwater site and enriched signatures (from $-19.1 \%$ to $-12.3 \%$ ) in the mixohaline area near the estuary mouth (Fig. 2). ANOVA revealed a significant effect of location on $\delta^{13} \mathrm{C}$ values of species assemblages $(F=33.54, p<0.001)$.
Mean $\delta^{13} \mathrm{C}$ values of fishes from the two estuarine sites (B and C, Fig. 3, upper graph) were not significantly different (Newman-Keuls post hoc test).

Although showing higher within-site variance than carbon signatures, $\delta^{15} \mathrm{~N}$ signatures were significantly enriched upstream than at downstream sites $(F=9.00, p<0.001$, Fig. 2). Mean $\delta^{15} \mathrm{~N}$ was significantly enriched at site A compared to both estuarine sites (Newman-Keuls test) (Fig. 3, lower graph). Sites $\mathrm{B}$ and $\mathrm{C}$ did not differ significantly in mean assemblage $\delta^{15} \mathrm{~N}$ values (Newman-Keuls test, Fig. 3, lower graph).

Freshwater taxa had depleted carbon ratios $(<-17.8 \%$ oo even when captured at estuarine sites B and C, the only exception being the pearl cichlid, Geophagus brasiliensis, which had the most enriched carbon signature $(-17.8 \%$ among freshwater fishes. The pearl cichlid is considered a secondary-division freshwater fish, a species belonging to a freshwater family with tolerance to salinity (Myers, 1938). In contrast, estuarine-dependent fishes tended to show less enriched carbon signatures when captured from the freshwater site of the lagoon (Fig. 2). Only three estuarine-dependent species (white sea catfish, whitemouth croaker and silverside) were captured from all three study sites. These species had significantly depleted carbon ratios in the freshwater site (Fig. 2, Table 2), a pattern similar to that observed for the overall fish assemblages.

Analysis of nitrogen isotope ratios yielded approximately three consumer trophic levels in both freshwater (A) and estuarine (B, C) sites. An exception was the white sea catfish, which occupied the 3rd consumer trophic position in freshwater and the 4th position in the estuary (Fig. 4). This difference could be associated with size differences of individuals captured at these sites. Catfish sampled at freshwater were larger (mean total length $=367.5 \pm 33.2 \mathrm{~mm}$ ) than in the estuary (mean $\mathrm{TL}=94.0 \pm 8.5 \mathrm{~mm}$ ). The lack of replicate samples for this species within the estuary did not allow a statistical test.

Fish species constituted a fairly continuous gradient of trophic positions in both freshwater and estuarine regions. This trend hindered categorization of fishes into distinct trophic levels. For those fish species captured from both freshwater and estuarine sites (e.g. croaker, sabertooth anchovy, silverside, characid, mullet), their trophic position estimates differed by only $0-0.5$ trophic levels between sites.

\section{Discussion}

\subsection{Community level carbon isotope signatures in freshwater and estuarine zones}

Fish assemblages showed a significant shift in their mean carbon isotopic signatures between the freshwater and estuarine zones of Patos Lagoon. Depleted carbon signatures (from $-24.7 \%$ to $-17.8 \%$ ) of fishes (mostly freshwater species) found in the freshwater site contrasted with more enriched signatures (from $-19.1 \%$ to $-12.3 \%$ ) of fishes (mostly estuarine dependent and estuarine resident species) within the brackish waters near the estuary's mouth. A similar $\delta{ }^{13} \mathrm{C}$ ratio 
Table 1

$\delta^{13} \mathrm{C}$ and $\delta^{15} \mathrm{~N}$ values of most representative plants found at the freshwater $(\mathrm{A})$ and estuarine $(\mathrm{B}, \mathrm{C})$ sites. $\mathrm{C}_{3}$ and $\mathrm{C}_{4}$ plants are denoted in parentheses. Data source: 1, this study; 2, Abreu et al. (2006)

\begin{tabular}{|c|c|c|c|c|}
\hline$\overline{\text { Species }}$ & Occurrence & ${ }^{13} \mathrm{C}$ & ${ }^{15} \mathrm{~N}$ & $\overline{\text { Source }}$ \\
\hline \multicolumn{5}{|l|}{ Freshwater (A) } \\
\hline Scirpus californicus $\left(\mathrm{C}_{3}\right)$ & at lower freshwater marsh & -26.12 & 5.67 & 1 \\
\hline Salvinia sp. $\left(\mathrm{C}_{3}\right)$ & at water surface & -27.80 & 7.10 & 1 \\
\hline Eichhornia azurea $\left(\mathrm{C}_{3}\right)$ & at water surface & -28.59 & 7.41 & 1 \\
\hline Polygonum sp. $\left(\mathrm{C}_{3}\right)$ & at middle freshwater marsh & -28.95 & 10.28 & 1 \\
\hline Pistia striolates $\left(\mathrm{C}_{3}\right)$ & at water surface & -27.82 & 10.45 & 1 \\
\hline Enhydra sp. $\left(\mathrm{C}_{3}\right)$ & at middle freshwater marsh & -30.44 & 11.50 & 1 \\
\hline Eichhornia crassipes $\left(\mathrm{C}_{3}\right)$ & at water surface & -27.96 & 12.24 & 1 \\
\hline Mean & & -28.24 & 9.23 & \\
\hline SD & & 1.32 & 2.49 & \\
\hline \multicolumn{5}{|l|}{ Estuary (B) } \\
\hline Spartina densiflora $\left(\mathrm{C}_{4}\right)$ & at higher saltmarsh grounds & -11.60 & 6.71 & 1 \\
\hline Juncus kraussii $\left(\mathrm{C}_{3}\right)$ & at higher saltmarsh grounds & -26.33 & 5.37 & 1 \\
\hline Cyperus giganteus $\left(\mathrm{C}_{3}\right)$ & at wet (freshwater) fields near higher marshes & -27.97 & 5.64 & 1 \\
\hline Scirpus maritimus $\left(\mathrm{C}_{3}\right)$ & at lower saltmarsh grounds & -27.28 & 7.42 & 1 \\
\hline Cladium jamaicense $\left(\mathrm{C}_{3}\right)$ & at lower freshwater-saltmarsh transition & -27.52 & 7.75 & 1 \\
\hline Mean & & -24.14 & 6.58 & \\
\hline SD & & 7.04 & 1.05 & \\
\hline \multicolumn{5}{|l|}{ Estuary (C) } \\
\hline Spartina densiflora $\left(\mathrm{C}_{4}\right)$ & at higher saltmarsh grounds & -10.83 & 8.90 & 2 \\
\hline Spartina alterniflora $\left(\mathrm{C}_{4}\right)$ & at lower saltmarsh grounds & -11.42 & 11.43 & 2 \\
\hline Ruppia maritima $\left(\mathrm{C}_{4}\right)$ & as monospecific seagrass bed & -11.84 & 8.05 & 2 \\
\hline Juncus kraussii $\left(\mathrm{C}_{3}\right)$ & at higher saltmarsh grounds & -27.69 & 5.89 & 1 \\
\hline Scirpus olneyi $\left(\mathrm{C}_{3}\right)$ & at lower saltmarsh grounds & -26.06 & 9.16 & 2 \\
\hline Scirpus maritimus $\left(\mathrm{C}_{3}\right)$ & at lower saltmarsh grounds & -26.39 & 7.27 & 2 \\
\hline Mean & & -19.04 & 8.45 & \\
\hline SD & & 8.43 & 1.88 & \\
\hline
\end{tabular}

shift between freshwater (from $-29 \%$ to $-21 \%$ ) and estuary (from $-23 \%$ to $-15 \%$ ) consumers was reported to occur in the Plum Island Sound estuarine system (Deegan and Garritt, 1997). Based on a detailed isotopic composition analysis $\left({ }^{13} \mathrm{C}\right.$, ${ }^{15} \mathrm{~N},{ }^{34} \mathrm{~S}$ ) of primary producers, these authors suggested that consumers tended to rely on locally produced organic matter. Other studies (Peterson et al., 1985; Kang et al., 2003; Doi et al., 2005) also have shown that the use and importance of primary producers ultimately providing carbon sources for consumers changes considerably over the length of estuarine and coastal systems.

Patos Lagoon has a highly diverse primary producer community; approximately 70 species of tidal marsh and wetland plants, five submersed spermatophytes, 94 benthic algal species and a heterogeneous group of microalgae (Seeliger et al., 1996). However, the estuarine zone of the lagoon is largely dominated by salt-marshes (e.g., Spartina, Juncus, Scirpus) and monospecific beds of the widgeon grass Ruppia maritima. Salt-marshes occupy approximately $70 \mathrm{~km}^{2}$ of the intertidal zone, whereas $R$. maritima covers approximately $120 \mathrm{~km}^{2}$ of the estuarine bottom between 0.3 and $1.5 \mathrm{~m}$ depth. Both primary producers constitute vital habitats for several estuarine and marine organisms, including crustacean and fish species (Costa et al., 1997). These salt marshes and seagrass beds (mostly $\mathrm{C}_{4}$ plants) did not occur in the freshwater reaches of the lagoon where freshwater marsh and floating species (mostly $\mathrm{C}_{3}$ plants) predominate (Seeliger et al., 1996). Macrophytes sampled at the three study sites revealed a $\delta^{13} \mathrm{C}$ range concordant with values reported in the literature for terrestrial plants using the $\mathrm{C}_{3}$ photosynthetic pathway $(-23 \%$ and $-30 \%$, Smith and Epstein, $1971 ;-26.8 \%$ and $28.9 \%$, Deegan and Garritt, 1997) rather than the relatively enriched signatures shown by species that employ the $\mathrm{C}_{4}$ photosynthetic pathway (between $-12.9 \%$ and $-15.8 \%$, Deegan and Garritt, 1997; $-10 \%$ and $-16 \%$, Forsberg et al., 1993).

Based on our survey of the $\mathrm{C}_{3}$ and $\mathrm{C}_{4}$ macrophytes and isotopic values for phytoplankton and benthic microalgae reported in the literature for ecosystems elsewhere (Peterson and Fry, 1987; Deegan and Garritt, 1997; Kang et al., 2003), we hypothesized that the observed $\delta^{13} \mathrm{C}$ differences in the fish assemblage between freshwater and estuarine sites is due to a shift from assimilating organic matter ultimately derived from $\mathrm{C}_{3}$ freshwater marsh vegetation and phytoplankton at the freshwater site $\left(\delta^{13} \mathrm{C}\right.$ ranging from $-25 \%$ to $-19 \%$, to $\mathrm{C}_{4}$ salt-marshes (e.g. Spartina) and widgeon grass (Ruppia maritima), benthic microalgae and marine phytoplankton at the estuarine sites (from $-18 \%$ to $-12 \%$ ). Our current data for $\mathrm{C}_{3}$ and $\mathrm{C}_{4}$ plants seem to corroborate this hypothesis. However, the lack of data for phytoplankton (freshwater/marine) and benthic microalgae at our sites hinders a detailed evaluation of the proportional carbon contribution of local primary producers to fish nutrition. 
Table 2

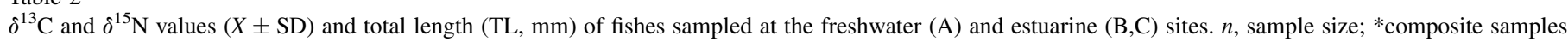

\begin{tabular}{|c|c|c|c|c|c|}
\hline Common name & Species & $n$ & $\mathrm{TL}$ & ${ }^{13} \mathrm{C}$ & ${ }^{15} \mathrm{~N}$ \\
\hline \multicolumn{6}{|l|}{ Freshwater (A) } \\
\hline Characid & Astyanax spp & 2 & $104.9 \pm 45.4$ & $-20.25 \pm 1.9$ & $11.82 \pm 0.3$ \\
\hline Characid & Astyanax alburnus & $3 *$ & $45.3 \pm 1.5$ & -20.14 & 12.84 \\
\hline Characid & Astyanax bimaculatus & $5 *$ & $74.6 \pm 7.6$ & -21.50 & 10.50 \\
\hline Characid & Astyanax eigenmanniorum & $2 *$ & $64.0 \pm 9.9$ & -24.60 & 10.94 \\
\hline Characid & Astyanax fasciatus & 3 & $82.7 \pm 40.7$ & $-21.85 \pm 1.6$ & $11.26 \pm 0.9$ \\
\hline Pike cichlid & Crenicichla punctata & 1 & 128.0 & -18.72 & 12.00 \\
\hline Atlantic sabretooth anchovy & Lycengraulis grossidens & 4 & $139.2 \pm 77.1$ & $-19.25 \pm 2.2$ & $13.78 \pm 1.0$ \\
\hline Silverside & Odontesthes argentinensis & 2 & $107.0 \pm 1.8$ & $-19.99 \pm 0.7$ & $12.40 \pm 0.0$ \\
\hline Dog-tooth characid & Oligosarcus robustus & 1 & 96.0 & -19.93 & 14.17 \\
\hline \multirow{2}{*}{ River Plate sprat } & Platanichthys platana & 3 & $78.1 \pm 3.0$ & $-20.77 \pm 0.4$ & $12.57 \pm 0.8$ \\
\hline & Cyphocharax voga & 2 & $105.3 \pm 32.0$ & $-22.04 \pm 1.0$ & $9.89 \pm 0.6$ \\
\hline Pearl cichlid & Geophagus brasiliensis & 3 & $105.3 \pm 22.7$ & $-20.14 \pm 0.3$ & $13.20 \pm 0.3$ \\
\hline White sea catfish & Netuma barba & 2 & $367.5 \pm 33.2$ & $-22.43 \pm 1.5$ & $14.82 \pm 1.3$ \\
\hline Freshwater catfish & Pimelodella laticeps australis & 2 & $75.3 \pm 6.1$ & $-20.81 \pm 0.5$ & $13.48 \pm 0.4$ \\
\hline Freshwater catfish & Pimelodus maculates & 2 & $234.8 \pm 73.9$ & $-22.59 \pm 2.7$ & $13.50 \pm 0.3$ \\
\hline Freshwater catfish & Rhamdia sapo & 1 & 185.0 & -24.70 & 9.29 \\
\hline Whitemouth croaker & Micropogonias furnieri & 3 & $198.7 \pm 94.9$ & $-17.97 \pm 1.1$ & $14.39 \pm 0.3$ \\
\hline Freshwater catfish & Parapimelodus nigribarbis & 2 & $117.1 \pm 0.8$ & $-17.83 \pm 0.5$ & $11.63 \pm 0.0$ \\
\hline Trahira & Hoplias malabaricus & 2 & $165.0 \pm 45.3$ & $-22.38 \pm 0.5$ & $9.60 \pm 0.9$ \\
\hline \multicolumn{6}{|l|}{ Estuary (B) } \\
\hline Brazilian silverside & Atherinella brasiliensis & $2 *$ & $95.0 \pm 1.4$ & -14.61 & 12.29 \\
\hline Silverside & Odontesthes argentinensis & 3 & $63.7 \pm 24.9$ & $-17.69 \pm 0.7$ & $9.81 \pm 0.2$ \\
\hline River Plate sprat & Platanichthys platana & $8 *$ & $68.6 \pm 15.8$ & -19.15 & 11.07 \\
\hline Mullet & Mugil platanus & $6 *$ & $26.5 \pm 2.7$ & -19.35 & 8.15 \\
\hline Flounder & Achirus garmani & 3 & $131.3 \pm 6.0$ & $-14.80 \pm 1.4$ & $11.01 \pm 0.6$ \\
\hline Cichlid & Geophagus brasiliensis & 3 & $108.3 \pm 4.5$ & $-17.81 \pm 3.8$ & $8.84 \pm 0.6$ \\
\hline Goby & Gobionellus shufeldti & $9 *$ & $56.6 \pm 7.2$ & -13.32 & 9.58 \\
\hline White sea catfish & Netuma barba & 2 & $114.3 \pm 22.2$ & $-18.26 \pm 0.8$ & $10.91 \pm 0.5$ \\
\hline One-sided livebearer & Jenynsia multidentata & $5 *$ & & -18.60 & 8.13 \\
\hline Whitemouth croaker & Micropogonias furnieri & 3 & $151.7 \pm 9.9$ & $-15.28 \pm 1.5$ & $9.60 \pm 0.5$ \\
\hline Trahira & Hoplias malabaricus & 3 & $275.3 \pm 5.5$ & $-21.98 \pm 0.2$ & $10.83 \pm 0.3$ \\
\hline \multicolumn{6}{|l|}{ Estuary (C) } \\
\hline Characid & Astyanax eigenmanniorum & $11 *$ & $41.0 \pm 8.5$ & -23.94 & 7.65 \\
\hline Argentine menhaden & Brevoortia pectinata & $25 *$ & $37.5 \pm 3.5$ & -17.17 & 9.47 \\
\hline Atlantic sabretooth anchovy & Lycengraulis grossidens & 1 & 85.0 & -17.82 & 11.00 \\
\hline Silverside & Odontesthes argentinensis & 2 & $70.7 \pm 41.2$ & $-16.45 \pm 0.2$ & $10.58 \pm 0.1$ \\
\hline Mullet & Mugil platanus & 2 & $49.5 \pm 6.4$ & $-14.51 \pm 1.1$ & $8.54 \pm 0.4$ \\
\hline Bay whiff & Citharichthys spilopterus & 1 & & -15.23 & 10.59 \\
\hline Flounder & Paralichthys orbignyanus & $2 *$ & $102.0 \pm 5.7$ & -12.37 & 11.64 \\
\hline Tonguefish & Symphurus jenynsi & 2 & $77.0 \pm 29.0$ & $-14.90 \pm 1.8$ & $12.71 \pm 0.8$ \\
\hline Guri sea catfish & Genidens genidens & $5 *$ & $94.0 \pm 9.9$ & -16.45 & 12.03 \\
\hline White sea catfish & Netuma barba & $4 *$ & $94.0 \pm 8.5$ & -15.27 & 15.51 \\
\hline One-sided livebearer & Jenynsia multidentata & $8 *$ & $43.5 \pm 14.8$ & -18.60 & 8.13 \\
\hline Whitemouth croaker & Micropogonias furnieri & 3 & $129.3 \pm 9.0$ & $-13.93 \pm 1.6$ & $13.05 \pm 2.1$ \\
\hline
\end{tabular}

\subsection{Carbon sources and fishes' movements within the lagoon}

Analysis of isotopic signatures based on estuarine ecological guilds [freshwater vs. estuarine resident/dependent fishes, sensu Garcia et al. (2003a)] and previous life-history studies within Patos Lagoon (Chao et al., 1985; Bemvenuti, 1987; Vieira, 1991; Vieira and Castello, 1996) provide evidence corroborating the general hypothesis that consumers reflected autochthonous organic matter production. For example, only three freshwater species were captured at the estuarine zone at the lower reaches of the lagoon: two primary-division freshwater fishes (the trahira Hoplias malabaricus and the characid
Astyanax eigenmaniorum) and one second-division freshwater fish (Pearl cichlid Geophagus brasiliensis). Primary-division freshwater families are strictly confined to freshwater, whereas secondary-division freshwater families are generally restricted to freshwater but may occasionally enter salt water (Myers, 1938). Previous long-term analysis of spatiotemporal distribution patterns of freshwater fishes in Patos Lagoon have shown that primary-division fishes inhabiting the freshwater site (in the upper lagoon) can be flushed into the estuarine zone during periods of high freshwater discharge (Garcia et al., 2003b). These species remain brief periods within the estuary. After the return of normal hydrological conditions these freshwater vagrant fishes probably follow receding freshwater back to 
A
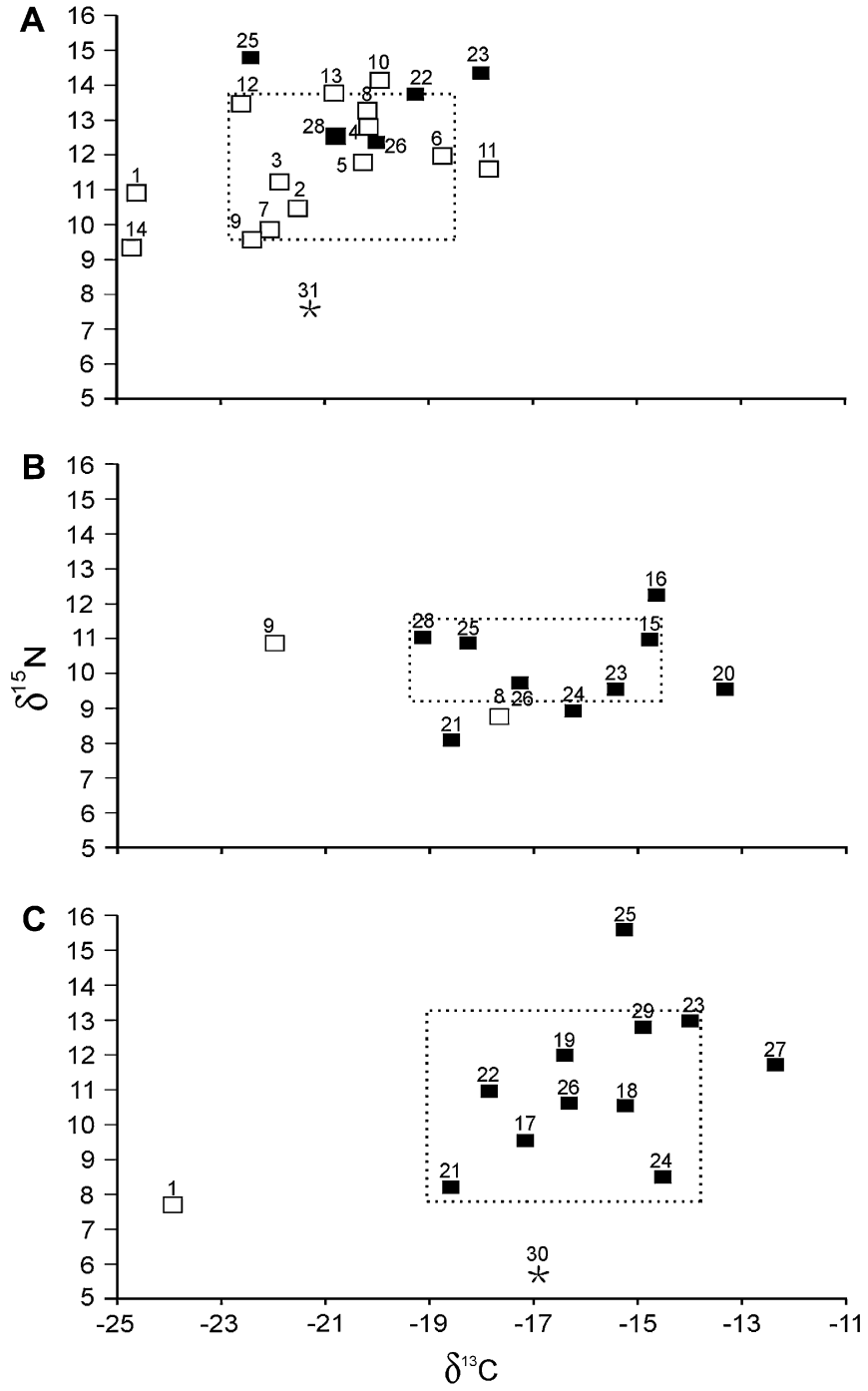

Fig. 2. Plot of $\delta^{15} \mathrm{~N}$ and $\delta^{13} \mathrm{C}$ values for fishes at freshwater (A) and estuarine (B, C) sites. Dashed boxes represent one standard deviation around the mean $\delta^{15} \mathrm{~N}$ and $\delta^{13} \mathrm{C}$ values for each site. Sources of carbon assimilated by consumers are indicated by the relative positions of taxa on the $x$-axis; trophic level is indicated by relative position on the $y$-axis. Species codes: Freshwater fishes ( $\square$ ) 1, Astyanax eigenmanniorum; 2, Astyanax bimaculatus; 3, Astyanax fasciatus; 4, Astyanax alburnus; 5, Astyanax sp.; 6, Crenicichla punctata; 7, Cyphocharax voga; 8, Geophagus brasiliensis; 9, Hoplias malabaricus; 10, Oligosarcus robustus; 11, Parapimelodus nigribarbis; 12, Pimelodella laticeps australis; 13, Pimelodus maculatus; 14, Rhamdia sapo; Estuarine and marine fishes (ם) 15, Achirus garmani; 16, Atherinella brasiliensis; 17, Brevoortia pectinata; 18 , Citharichthys spilopterus; 19, Genidens genidens; 20, Gobionellus shufeldti; 21, Jenynsia multidentata; 22, Lycengraulis grossidens; 23, Micropogonias furnieri; 24, Mugil platanus; 25, Netuma barba; 26, Odontesthes argentinensis; 27, Paralichthys orbignyanus; 28, Platanichthys platana; 29, Symphurus jenynsi; Bivalves ( $\star$ ) 30, Erodona mactroides; 31, Limnoperna fortunei.

upper lagoon reaches and/or suffer high mortality induced by physiological stress due to intrusion of saline water into the estuary (Garcia et al., 2003a). The second-division freshwater cichlid is predictably found year-round in low densities within the estuary regardless of variation in salinity (Garcia et al., 2003b). Accordingly, $\delta^{13} \mathrm{C}$ signatures of the freshwater vagrants (trahira and characid) captured within the estuary
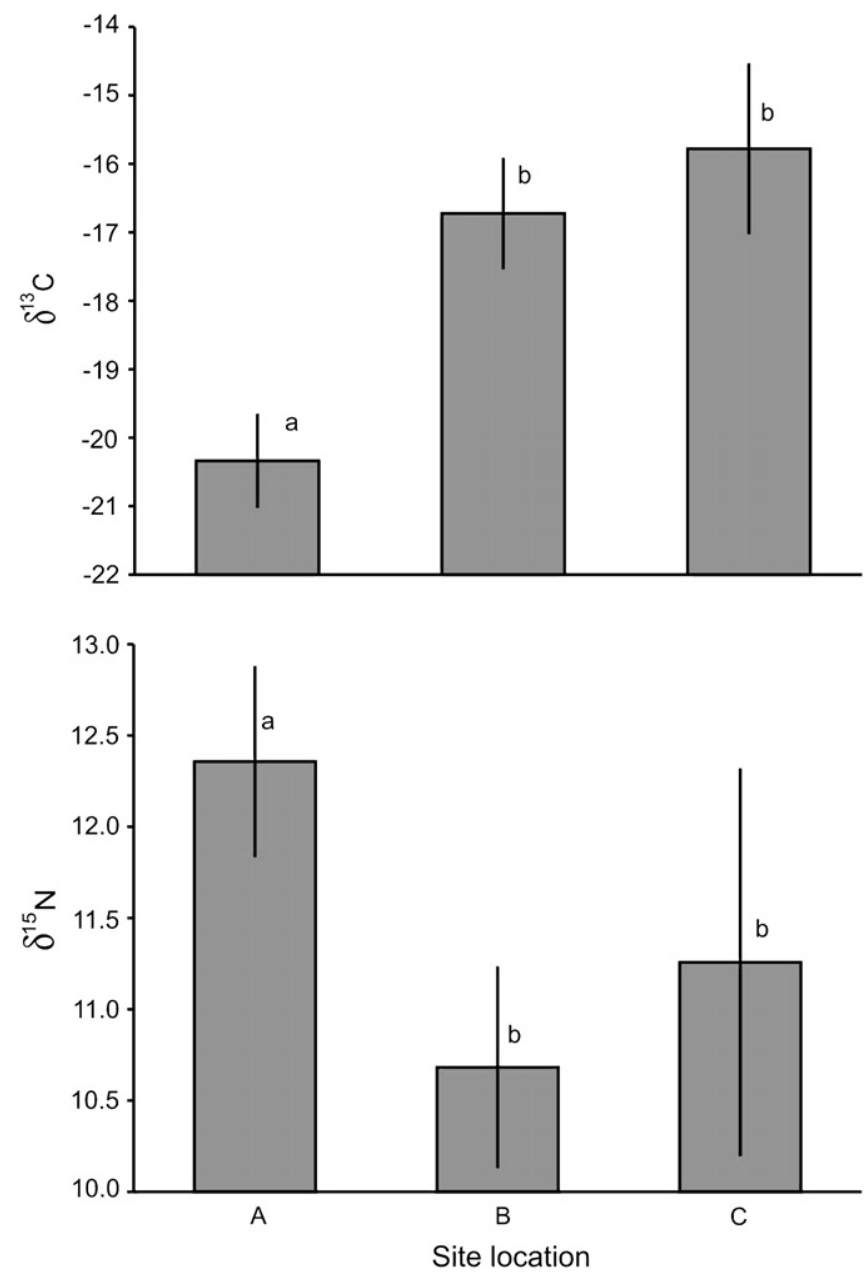

Fig. 3. Mean ( $\pm 1 \mathrm{SD}) \delta^{13} \mathrm{C}$ and $\delta^{15} \mathrm{~N}$ values for each fish assemblage at each sampling location (A: freshwater and B, C: estuary). Lowercase letters (a, b, c) denote pairwise comparisons of sampling locations means.

were depleted, similar to signatures of those freshwater fishes inhabiting the upper lagoon. In contrast, the salinity tolerant Geophagus brasiliensis had a more enriched $\delta^{13} \mathrm{C}$ signature, in the same range of other estuarine dependent and resident fishes found within the estuary.

In contrast with freshwater fishes, which can be passively transported from the freshwater site into the estuarine zone downstream due to high freshwater discharge (Garcia et al., 2004), some euryhaline estuarine fishes can actively move into the freshwater site of Patos Lagoon during part of their life cycle (Chao et al., 1985; Vieira and Castello, 1996). For instance, whitemouth croaker (Micropogonias furnieri) spawns off the coast near the Patos Lagoon estuary and represents one of the most abundant fish within the lagoon and its estuarine zone (Chao et al., 1985). Their young-of-the-year inhabit shallow estuarine waters, but after achieving larger sizes $(>150 \mathrm{~mm})$, these individuals move to deeper waters of the lagoon's channel, from where they can move to the upper freshwater reaches of the lagoon (Vieira and Castello, 1996). Part of its population has been hypothesized to remain in the freshwater site until mature adults start migrating out of the lagoon to reproduce in marine waters. Our isotopic data 

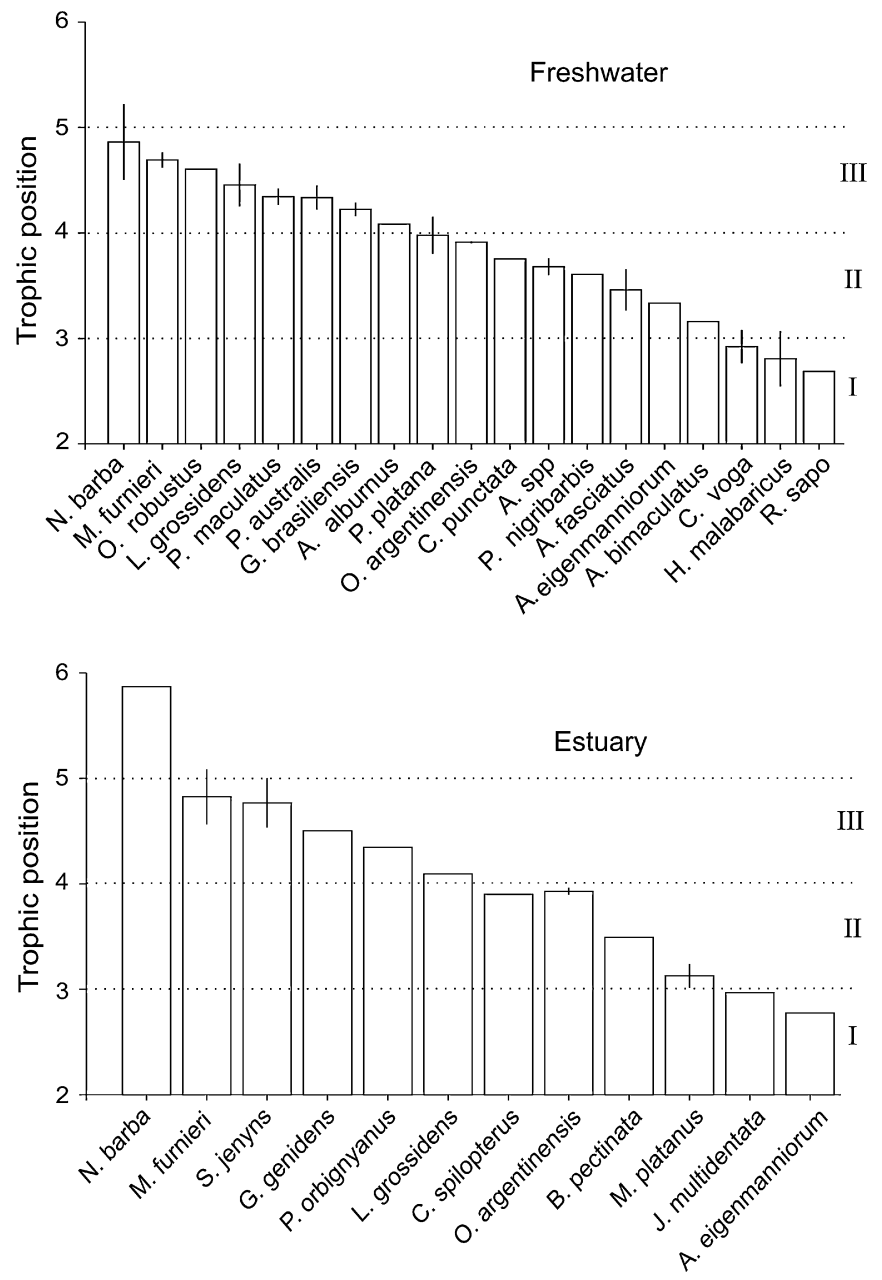

Fig. 4. Trophic position estimates of fishes collected at freshwater (A) and estuary $(C)$ locations. Dashed lines designate consumer trophic levels.

provides indirect evidence that whitemouth croaker sub-adults remain prolonged periods in freshwater. Individuals captured at the freshwater site had significantly depleted average $\delta^{13} \mathrm{C}$ signatures $(-17.97 \%)$ compared with individuals caught within the estuary (site B: $-15.28 \%$ and site C: $-13.93 \%$ ). Apparently, whitemouth croaker remain in freshwater long enough to have their $\delta^{13} \mathrm{C}$ signatures shift from an originally enriched signature (obtained during their juvenile stage within the estuary) to a more depleted signature reflecting autochthonous freshwater organic matter. Although multiple factors may affect tissue turnover rates, a relatively rapid $(<3$ mo.) turnover in isotope signatures reflecting incorporation of new food sources has been reported for other fishes (Hesslein et al., 1993).

\subsection{Variation in nitrogen isotope ratios and vertical trophic structure}

Nitrogen isotopic ratios of fishes showed significant differences between the freshwater site and the brackish estuarine sites. The freshwater assemblage had a more enriched mean $\delta^{15} \mathrm{~N}$ signature than both estuarine assemblages. White sea catfish, whitemouth croaker and silverside, which occurred across all sites, also showed a tendency to have more enriched $\delta^{15} \mathrm{~N}$ values in freshwater compared to estuarine sites.

The observed $\delta^{15} \mathrm{~N}$ shift could be simply due to the marked differences in nitrogen supply and its biogeochemical transformations (Valiela, 1995) at the study sites. The freshwater site receives high nutrient loads (phosphate and nitrogen) from the major tributaries of the lagoon that drain large-scale agricultural and urban areas. This elevated nutrient load suffers substantial reduction during its transport to the lower reaches of the lagoon where the estuarine sites B and C are located (Seeliger and Costa, 1996). Additionally, wastewater $\mathrm{N}$ in groundwater usually has enriched $\delta^{15} \mathrm{~N}$ values $(10-22 \%$ ) because mineralization processes (amonification and denitrification) leave wastewater-derived nitrate enriched in ${ }^{15} \mathrm{~N}$ relative to groundwater $\mathrm{N}$ derived from atmospheric deposition (2$8 \%$ ) and fertilizer (-3\% to 3\%) (McClelland and Valiela, 1998; Cole et al., 2004). It can be speculated that groundwater in the freshwater site is more enriched in ${ }^{15} \mathrm{~N}$ than estuarine groundwater. Such difference could lead to a higher N baseline for the freshwater food web compared to the estuary.

In theory, more productive systems are considered to support more feeding links and trophic levels (Briand and Cohen, 1987). Although mixohaline waters of Patos Lagoon are much more productive than its upper oligotrophic zone (Castello, 1985), we did not observe considerable differences in terms of food-chain length between both regions. In part, this finding can be explained by the absence of resident piscivorous fishes within Patos Lagoon estuary (Vieira and Castello, 1996). In contrast with other estuaries [e.g. Chesapeake Bay, Day (1989)] where piscivorous fishes are important food-web components, they do not play an important role within Patos Lagoon estuary. Usually they are restricted to a few marine piscivores (e.g., bluefish Pomatomus saltatrix, largehead hairtail Trichiurus lepturus) that move into the estuary in low numbers during summer months (Chao et al., 1985). Or, as has been demonstrated recently by Garcia et al. (2003a), piscivorous fishes such as the dog-tooth characid Oligosarcus jenynsii can be flushed into the estuary by exceptionally high freshwater discharge trigged by El Niño events. These marine and freshwater piscivores were not found within the estuary during our sampling surveys.

In conclusion, this study showed fundamental differences in primary food web structure of estuarine and freshwater habitats of Patos Lagoon, one of the largest subtropical lagoons in the world. Trophic position among species is characterized by a continuum, with most fishes occupying the secondary and tertiary consumer level. While local production appears to support fish assemblages in both freshwater and estuarine zones of the lagoon, the ultimate sources differ. Freshwater assemblages appear to be based on $\mathrm{C}_{3}$ freshwater marsh plants and phytoplankton production, whereas estuarine assemblages are likely based on carbon derived from $\mathrm{C}_{4}$ salt-marsh and widgeon grass, benthic microalgae, and marine phytoplankton. Further sampling of primary producers in the study sites, particularly microphytes, are needed in order to test this hypothesis. As one of the first studies in South American estuaries to 
use SIA to determine energy flow and aquatic food web structure, this work is an important baseline for future investigations in Neotropical estuaries, and provides a basis for comparisons with other estuarine systems elsewhere.

\section{Acknowledgments}

Thanks to the numerous colleagues and technicians that assist in the field and laboratory work, especially A.C. Mai, F. Roselet and V. Condini; to C.S.B. Costa for providing assistance during sample pre-preparation; to P.C. Abreu for suggestions during manuscript preparation. A.M.G. acknowledges fellowship support provided by CNPq (Grant 150868/20030). D.J.H. was supported in part by research scholarships from the Society of Wetland Scientists. Facilities were made available to D.J.H. at the Research Nucleus in Limnology, Ichthyology and Aquaculture (Nupélia) at the State University of Maringá (UEM), Brazil.

\section{References}

Abreu, P.A., Anésio, A.M., Costa, C., Bemvenuti, C., Odebrecht, C., Granéli, W., 2006. Eutrophication processes and trophic interactions in a shallow estuary: preliminary results based on stable isotope analysis $\left(\delta^{13} \mathrm{C}\right.$ and $\left.\delta^{15} \mathrm{~N}\right)$. Estuaries 29, 277-285.

Bemvenuti, M.A., 1987. Abundância, distribuição e reprodução de peixes-rei (Atherinidae) na região estuarina da Lagoa dos Patos, RS, Brasil. Atlântica 9, 5-32.

Briand, F., Cohen, J.E., 1987. Environmental correlates of food chain length. Science 238, 956-960.

Castello, J.P., 1985. La ecologia de los consumidores del estuarino de la Lagoa dos Patos, Brasil. In: Yanez-Arancibia, A. (Ed.), Fish Community Ecology in Estuaries and Coastal Lagoons: Towards an Ecosystem Integration. DR (R) UNAM Press, Mexico, pp. 383-406.

Chao, L.H., Pereira, L.E., Vieira, J.P., 1985. Estuarine fish community of the dos Patos Lagoon, Brazil. A baseline study. In: Yanez-Arancibia, A. (Ed.), Fish Community Ecology in Estuaries and Coastal Lagoons: Towards an Ecosystem Integration. DR (R) UNAM Press, Mexico, pp. 429-450.

Cole, M.L., Valiela, I., Kroeger, K.D., Tomasky, G.L., Cebrian, J., Wigand, C., McKinney, R.A., Grady, S.P., da Silva, M.H.C., 2004. Assessment of a delta $\mathrm{N}-15$ isotopic method to indicate anthropogenic eutrophication in aquatic ecosystems. Journal of Environmental Quality 33, 124-132.

Connolly, R.M., Hindell, J.S., Gorman, D., 2005. Seagrass and epiphytic algae support nutrition of a fisheries species, Sillago schomburgkii, in adjacent intertidal habitats. Marine Ecology Progress Series 286, 69-79.

Cook, P.L.M., Revill, A.T., Clementson, L.A., Volkman, J.K., 2004. Carbon and nitrogen cycling on intertidal mudflats of a temperate Australian estuary. III. Sources of organic matter. Marine Ecology Progress Series 280, $55-72$.

Costa, C.S.B., Seeliger, U., Oliveira, C.P.L., Mazo, A.M.M., 1997. Distribuição, funções e valores das marismas e pradarias submerses no estuário da Lagoa dos Patos (RS, Brasil). Atlântica 19, 67-85.

Day, J.W., Hall, C.A.S., Kemp, W.M., Yanez-Arancibia, A., 1989. Estuarine ecology. John Wiley and Sons, New York.

Deegan, L.A., Garritt, R.H., 1997. Evidence for spatial variability in estuarine food webs. Marine Ecology Progress Series 147, 31-47.

Doi, H., Matsumasa, M., Toya, T., Satoh, N., Mizota, C., Maki, Y., Kikuchi, E., 2005. Spatial shifts in food sources for macrozoobenthos in an estuarine ecosystem: carbon and nitrogen stable isotope analyses. Estuarine, Coastal and Shelf Science 64, 316-322.

Forsberg, B.R., Araújo-Lima, C.A.R.M., Martinelli, L.A., Victoria, R.L., Bonassi, J.A., 1993. Autotrophic carbon sources for fish of the central Amazon. Ecology 74, 643-652.
Garcia, A.M., Vieira, J.P., Winemiller, K.O., 2003a. Effects of 1997-1998 El Niño on the dynamics of the shallow-water fish assemblage of the Patos Lagoon estuary (Brazil). Estuarine, Coastal and Shelf Science 57, 489-500.

Garcia, A.M., Raseira, M.B., Vieira, J.P., Winemiller, K.O., Grimm, A.M., 2003b. Spatiotemporal variation in shallow-water freshwater fish distribution and abundance in a large subtropical coastal lagoon. Environmental Biology of Fishes 68, 215-228.

Garcia, A.M., Vieira, J.P., Winemiller, K.O., Grimm, A.M., 2004. Comparison of the 1982-1983 and 1997-1998 El Niño effects on the shallow-water fish assemblage of the Patos Lagoon estuary (Brazil). Estuaries 27, 905-914.

Haimovici, M., Castello, J.P., Vooren, C.M., 1996. Fisheries. In: Seeliger, U., Odebrecht, C., Castello, J.P. (Eds.), Subtropical Convergence Environments: The Coast and Sea in the Southwestern Atlantic. Springer Verlag, Berlin, pp. 183-196.

Hairston, N.G., Smith, F.E., Slobodkin, S.L., 1960. Community structure, population control, and competition. American Naturalist 94, 421-425.

Hesslein, R.H., Hallard, K.A., Ramlal, P., 1993. Replacement of Sulfur, Carbon, and Nitrogen in tissue of growing broad whitefish (Coregonus nasus) in response to a change in diet traced by delta-S-34, delta-C-13 and deltaN-15. Canadian Journal of Fisheries and Aquatic Sciences 50, 2071-2076.

Jepsen, D.B., Winemiller, K.O., 2002. Structure of tropical river food webs revealed by stable isotope ratios. Oikos $96,46-55$.

Kang, C.K., Kim, J.B., Lee, K.S., Lee, P.Y., Hong, J.S., 2003. Trophic importance of benthic microalgae to macrozoobenthos in coastal bay systems in Korea: dual stable $\mathrm{C}$ and $\mathrm{N}$ isotope analyses. Marine Ecology Progress Series 259, 79-92.

Kjerfve, B., 1986. Comparative oceanography of coastal lagoons. In: Wolfe, D.A. (Ed.), Estuarine Variability. Academic Press, Orlando, pp. $63-81$.

Litvin, S.Y., Weinstein, M.P., 2003. Life history strategies of estuarine nekton: the role of marsh macrophytes, benthic microalgae, and phytoplankton in the trophic spectrum. Estuaries 26, 552-562.

McClelland, J.W., Valiela, I., 1998. Linking nitrogen in estuarine producers to lan-derived sources. Limnology and Oceanography 43, 577-585.

McLusky, D.S., 1989. The Estuarine Ecosystem. Blackie, New York.

Melville, A.J., Connolly, R.M., 2003. Spatial analysis of stable isotope data to determine primary sources of nutrition for fish. Oecologia 136, 499-507.

Minagawa, M., Wada, E., 1984. Stepwise enrichment of N-15 along food-chains-further evidence and the relation between delta-N-15 and animal age. Geochimica et Cosmochimica Acta 48, 1135-1140.

Moller, O.O.J., Casting, P., Salomon, J.-C., Lazure, P., 2001. The influence of local and non-local forcing effects on the subtidal circulation of Patos Lagoon. Estuaries 24, 297-311.

Myers, G.S., 1938. Freshwater fishes and West Indian zoogeography. Annual Report of Smithsonian Institute 1937, 339-364.

Nybakken, J.W., Bertness, M.D., 2005. Marine Biology: An Ecological Approach. Benjamin Cummings, San Francisco.

Paine, R.T., 1969. The Pisaster-Tegula interaction: prey catches, predator food preference and intertidal community structure. Ecology 50, 950-961.

Paterson, A.W., Whitfield, A.K., 1997. A stable carbon isotope study of the foodweb in a freshwater-deprived South African estuary, with particular emphasis on the ichthyofauna. Estuarine, Coastal and Shelf Science 45, 705-715.

Pauly, D., Christensen, V., Dalsgaard, J., Froese, R., Torres Jr., F., 1998. Fishing down marine food webs. Science 279, 860-863.

Peterson, B.J., Fry, B., 1987. Stable isotopes in ecosystem studies. Annual Review of Ecology Evolution and Systematics 18, 293-320.

Peterson, B.J., Howarth, R.W., 1987. Sulfur, carbon and nitrogen isotopes used to trace organic matter flow in the salt-marsh estuaries of Sapelo Island, Georgia. Limnology and Oceanography 32, 1195-1213.

Peterson, B.J., Howarth, R.W., Garritt, R.H., 1985. Multiple stable isotope used to trace the flow of organic matter in estuarine food webs. Science 227, 1361-1363.

Polis, G.A., Winemiller, K.O., 1996. Food Webs: Integration of Patterns and Dynamics. Chapman and Hall, New York.

Post, D.M., 2002. Using stable isotopes to estimate trophic position: models, methods. and assumptions. Ecology 83, 703-718. 
Seeliger, U., Costa, C.S.B., 1996. Natural and human impact. In: Seeliger, U., Odebrecht, C., Castello, J.P. (Eds.), Subtropical Convergence Marine Ecosystem. The Coast and the Sea in the Warm Temperate Southwestern Atlantic. Springer Verlag, Berlin, pp. 197-203.

Seeliger, U., Kjerfve, B., 2001. Coastal Marine Ecosystems of Latin American. Springer Verlag, Berlin.

Seeliger, U., Odebrecht, C., Castello, J.P., 1996. Subtropical Convergence Environments: The Coast and Sea in the Southwestern Atlantic. Springer Verlag, Berlin.

Smith, B.N., Epstein, S., 1971. 2 Categories of C-13/C-12 ratios for higher plants. Plant Physiology 47, 380-384.

Sobczak, W.V., Cloern, J.E., Jassby, A.D., Cole, B.E., Schraga, T.S., Arnsberg, A., 2005. Detritus fuels ecosystem metabolism but not metazoan food webs in San Francisco estuary's freshwater Delta. Estuaries 28, 124-137.
Valiela, I., 1995. Marine Ecological Processes. Springer Verlag, New York. Vander Zanden, M.J., Rasmussen, J.B., 1996. A trophic position model of pelagic food webs: impact on contaminant bioaccumulation in lake trout. Ecological Monographs 66, 451-477.

Vanderklift, M.A., Ponsard, S., 2003. Sources of variation in consumer-diet d15N enrichment: a meta-analysis. Oecologia 136, 169-182.

Vieira, J.P., 1991. Juvenile mullets (Pisces: Mugilidae) in the estuary of Lagoa dos Patos, RS, Brazil. Copeia 1991, 409-418.

Vieira, J.P., Castello, J.P., 1996. Fish fauna. In: Seeliger, U., Odebrecht, C., Castello, J.P. (Eds.), Subtropical Convergence Marine Ecosystem. The Coast and the Sea in the Warm Temperate Southwestern Atlantic. Springer Verlag, Berlin, pp. 56-61.

Zaret, T.M., Paine, R.T., 1973. Species introduction in a tropical lake. Science $182,449-455$. 